\title{
Epiphany
}

Epiphany: Vol. 4, No. 1, 2011

ISSN 1840-3719

\section{Thinking With Glands - Jouissance of Women's Writing}

Alma Jeftic $\dot{\mathrm{c}}^{*}$

\begin{abstract}
This article seeks to explore the area of women's writing as to provide additional material for a discussion on the psychoanalytic perspective of gender development and the importance it has in the formation of female identity. With the attempt to review old debates on the existence of phallic and ovarian art, this article will contribute to it by providing a comparative study of Freudian and Lacanian theories of gender development. Oedipus myth and Freud's theories based on the phallus will be confronted with Lacan's theories. The main innovation of this article compared to the previous achievements in this field is the introduction of Lacan's term jouissance and its connection to female identity and the understandings of the childbirth metaphor. Jouissance represents surplus of enjoyment that can be explained through the resistance to prohibition, while the childbirth metaphor illustrates how gender creates and forms inscriptions of rules in female discourse. What can be concluded is that the significant number of female authors follow three phases: she tries to imitate her masculine colleagues, then she experiences the great feeling of resistance, and at the end she creates her own discourse, born through the processes of obedience and rebellion. While male writers can only create, women are able to both create and procreate. The childbirth metaphor has also served for centuries as a linguistic reunion of what culture and patriarchal literary tradition have sundered. By linking missing parts together, this article serves as a metaphor for one psychoanalitic movement towards jouissance of women's writing.
\end{abstract}

Key words: jouissance, childbirth metaphor, phallic and ovarian art, Oedipus myth

* Corresponding author: Alma Jeftić; Faculty of Arts and Social Sciences, International University of Sarajevo, Sarajevo, Bosnia and Herzegovina; e-mail: ajeftic@ius.edu.ba 


\section{Introduction}

The classic notions about women's artistic competences and literary styles are numerous and they are mostly based on the same facts. Female writing is often connected to female biology and the role a woman plays in society. Therefore, the main purpose of this article is to analyse women's writing and to provide topics for a discussion on psychoanalytic perspective of gender development and the importance it has in the formation of female identity. The comparative study of Freudian and Lacanian theories of gender development will be done with the attempt to provide solid ground for the analysis of women's writing.

The expansion of female authors was briefly summarized by Elaine Showalter. She described three phases of women's writing: feminine, feminist and female. Even though these phases represent the development of female literature through history, the same are deeply rooted in the work of each particular female author. Therefore, these phases can also be used with the aim to analyse each particular female author and her work.

The Oedipus myth and Freud's theories based on phallus will be confronted and analysed within the realm of Lacan's theories. The main innovation of this article compared to the previous achievements in this area is the introduction of Lacan's term jouissance and its connection to female identity and the understandings of childbirth metaphor. Jouissance will be analysed as a surplus of enjoyment and explained through the resistance to prohibition. Childbirth metaphor illustrates how gender creates and forms inscriptions of rules in female discourse. The conclusion is that the majority of female authors follow three phases: she tries to imitate her masculine colleagues, then she experiences the great feeling of resistance, and at the end she creates her own discourse, born through the processes of obedience and rebellion.

Contrary to the male writers who can only create, women are able to both create and procreate. Therefore childbirth metaphor has also served as a linguistic reunion of what culture and patriarchal literary tradition have sundered. While trying to find connection between the missing parts, this article serves as metaphor for one psychoanalitic movement towards the jouissance of women's writing. 


\section{Biological and Linguistic Models of Women's Writing}

The major differences between men and women lie in biology. Even though this implies that women think with their glands, while men are resonable and strong, there are other connotations relevant to this topic. Biological differences have caused the development of phallic and ovarian theories of art, as two different models. In an equivalent way, the special discourse of female writing has produced l'ecriture feminine, liberatory female writing of the future. In such writings women have always been easily degraded as the weaker sex by postulating psychophysical parallelism according to which the supposed physical weakness implies intellectual weakness (Bovenschen \& Weckmueller, 1977).

Victorian anthropologists believed that the frotal lobes of the male brain were heavier and more developed than female lobes and thus that women were inferior in intelligence (Showalter, 1981). German gynecologist Amann explained in 1874 hysteria as female mental disorder characterised by the severe gestures of wild animal (Lorenzer, 1984/1989). Hipokrat understood uterus as one special, animated animal able to feel, small and taste, as well as to move in all directions, towards heart, neck, head and liver (Lorenzer, 1984/1989). In an equivalent way Plato wrote that uterus is one animal who extremely wants to receive and who becomes furious when it does not recieve (Lorenzer, 1984/1989). These disseminations were documented in philosophical and medical proceedings of Greek and Latin physicians and thinkers. Hysteria was in that time a female disorder whilst uterus was its center. However, similar ideas and perceptions have been retained unchanged so far.

Ideology and the apportioning of roles subsumed women under the category of 'primary nature' (Bovenschen \& Weckmueller, 1977). But the simple retreat into anatomy and biology cannot be women's goal, since it will leave women in the world in which their biological make-up plays a societal role, whilst men live in their life of activity, science, technology and art. A biological view of women was described in Simone de Beauvoir's book "The Second Sex:"

Woman has ovaries, a uterus; these pecularities imprison

her in her subjectivity, circumscribe her within the limits 
of her own nature. It is often said that she thinks with her glands. Man superbly ignores the fact that his anatomy also includes glands, such as the testicles, and that they secrete hormones (Bovenschen \& Weckmueller, 1977, 121).

But does the biological difference in female writing exist? Are people really surrounded by phallic and ovarian art? It is not easy to give an appropriate answer to these questions. It is evident that in patriarchal Western culture the author is always a father, a progenitor, a procreator, anaesthetic patriarch whose pen is an instrument of generative power like his penis (Showalter, 1981).

Gilbert and Gubar did not provide the answer to their rethorical question: "If the pen is a metaphorical penis, from what organ can females generate texts?" (Showalter, 1981, 187), it has raised debates among female writers from one side, and feminists from the other. If women's writing proceeds from the body is there a possibility for metaphorical equation between literary creativity and childbirth, or, simply, is there a link between books and babies? The childbirth metaphor has been used by men and women for centuries, and it takes female anatomy as a model for human creativity in contrast with the phallic analogy, which uses male anatomy for its paradigm (StanfordFriedman, 1987). It validates women's artistic effort and helps them to get rid of an anxiety of authorship produced by the association of pen and paintbrush with phallus and masculinity.

From French theorists onwards, childbirth metaphor has been both accepted and rejected from female authors, as well as feminists. Whilst French theorists who promote the concept of l'ecriture feminine insist on a poetic of female body and writing "in white ink" as a milk metaphor, other authors, including Simone de Beauvoir, Elaine Showalter, Ann Rosalind Jones, Nina Auerbach and Erica Jong fear that it establishes a "counter-penis" and develops a regressive biologism (Stanford-Friedman, 1981). The phallus as a signifier functions in intersubjective economic analysis in order to specify large effects of the signified (Lacan, 1966/1983). According to Lacan (1966/2002) woman 
will ignore the vital feminine attributes in order to become phallus, i.e. signifier of the Other's wish. Therefore, the phallus becomes fetish accompanied by its function of signifier.

According to Freud there is only one id, and it is basically male. Female drives and intentions are based on the male's drives and intentions; therefore to him they are masculine by their origin. Freudian philosophy contributes to a masculine understanding of art, poetry and literature in general, due to its establishment on his understanding of woman as "castrated man." This view identifies pen and paintbrush (poetry and art) with masculine drives and the phallus as a signifier. However, radical feminist critics insist that biological differentiation and its relation to women's unity (mostly grounded in a Freudian view of woman) must be seriously redefined and pondered, since women's writing proceeds from the body and women sexual differentiation is also their source (Showalter, 1981). Considered both metaphorically and literary "writing the body" technique does not succeed according to the "phallic theories" criteria. Marie Cardinal's direct approach to writing the body appears to have played a role in the exclusion of her book "The Words to Say It" from the shortlist for the prestigious Prix Goncourt (Thomas \& Webb, 1999). She has argued that her description of the taboo subject of menstruation counted against her, therefore the same book with a prostate problem instead of uterine haemorrhaging would have been accepted (Thomas \& Webb, 1999).

The body as a source of self-knowledge, outside the damaging acculturation, exists in female art. Together with the $i d$ and jouissance it can sometimes bring down mountains of phallocentric delusions. But it is evident that only "writing the body" technique cannot change the position of "ovarian" versus "phallic" art. The realm of the body is seen as somewhat immune to social and gender conditions and able to issue forth a pure essence of the feminine (Barry, 2002). But its main aim is disclosure of the corporeal ground of female intelligence by producing an exhilarating challenge to phallic discourse in the clitoral, vulval, vaginal and uterine shape that traces the way to the white ink of female writing.

L'ecriture feminine - white ink of Ovarian art is well presented in the following poem: 
"Are you the poetess?

- Yes, Your Majesty! I am called thus!

You come from Silesia, do you not?

- Yes, Your Majesty!

Who was your father?

- He was a brewer from Schweidnitz, near the Grünberg vineyards.

But where were you born?

- On a dairy farm, like the one Horace had.

It is said that you never had instructions.

- Never, Your Majesty! My upbringing was of the worst sort!

But who helped you to became a poetess?

- Nature, and Your Majesty's victories.

But who thought you the roles?

- I know of no rules!

No rules? That is impossible! You must know the meter!

- Yes, Your Majesty! But I follow the meter from sound, and I know of no name for it.

But then how do you manage with language, if you never learned it?

- I have rather good control of my mother tongue!

I believe that, in terms of nuance, but what about the grammar?

- With regard to that, I can assure Your Majesty that I make only small mistakes..." (Bovenschen \& Weckmueller, 1977, 112)

Excerpt from a conversation between Anna Louise Karsch, called Sapho of Züllichau, and Frederick the Great, recorded in her own letter to Wilhelm Ludwig Gleim in 1763 serves as an example of women's exclusion from the artistic realm. The false equation of truth with the masculine perspective produces a phallocentric structure of language that reflects binary logic such as active/passive, masculine/feminine, 
head/heart, son/daughter, intelligent/sensitive, brother/sister, form/matter, phallus/vagina, reason/emotion (Murfin, 1999).

French feminists hold that this kind of language structure privileges the phallus and masculinity, but it posits woman as an idealized fantasy- fullfilment by associating language with separation from mother. Therefore, women are forced to choose between two possibilities: either they can imagine and represent themselves as men imagine and represent them or they can choose silence (Murfin, 1999). But some influential French feminists found another possibility- that women can develop a feminine language.

Annie Leclerc, Xaviere Gauthier, and Marguerite Duras discovered l'ecriture feminine or women's writing, based on the differences between male and female language, white and black, ovarian and phallic. According to Julia Kristeva, feminine language is semiotic, rhythmic and unifying. It is derived from the preoedipal period of fusion between mother and child, and it is also closely linked to the woman's body. Helene Cixous supports Kristeva's views in her essay titled „The Laugh of the Medusa":

To write. An act that will not only 'realize' the decensored relation of woman to her sexuality, to her womanly being, giving her access to her native strength; it will give her back her goods, her pleasure, her organs, her immense bodily territorities which have been kept under seal; it will tear her away from the super-egoized structure in which she has always occupied the place reserved for the guilty (guilty of everything, guilty at every turn: for having desires, for not having any; for being frigid, for being 'too hot'; for not being both at once; for being too motherly and not enough; for having children and for not having any; for nursing and for not nursing...) - tear her away by means of this research, this job of analysis and illumination, this emancipation of a marvelous text of her self that she must urgently learn to speak. A woman without a body, dumb, blind, can't possibly be a good fighter. She is reduced to being the servant of the militant 
male, his shadow. We must kill the false woman who is preventing the live one from breathing. Inscribe the breath of the whole woman (Cixous, 1976, 877).

What Cixous suggests is that if women are forced to remain in their bodies as a result of male repression they can either remain trapped inside the body, lost and passive, or, they can use the body as a medium of communication. That is some kind of transcendental function prescribed to the female body. At the same time it serves as a prison and as a vehicle for freedom and escape. On the same ground, Luce Irigaray argues that women's jouissance cannot be expressed by the dominant, ordered and logical masculine language, since women's jouissance is more multiple than men's unitary, phallic pleasure, and women has sex organs just about everywhere (Murfin, 1999).

What Kristeva, Cixous and Irigaray have in common is their emphasize of female sexuality and its importance in a masculine world. Cixous also insists on specific female libidinal impulses in women's unconscious and its presence in the liberatory female discourses. That is actually linguistic shift from Kristeva's semiotic discourse that represents incestuous challenge to the simbolic order towards Cixous liberatory female discourse of the future. This also poses a new question: can the body be the source of knowledge and new discourse? So far all the answers were based on female rereadings of Freud's and Lacan's psychoanalytic understandings of female anatomy, but none of them even tried to analyse it through a connection between Showalter's three phases of women's writing and psychoanalytic formation of gender identity.

\section{The Psychoanalytic Formation of Gender Identity}

The voice of the nymph in Marvell's poem "The Nymph complaining for the Death of her Faun" is hysterical, which calls to mind a cluster of characteristics useful in reading this poem (Gottlieb, 1999). The term hysteria involves linguistic and somatic disruptions that are at once strategies of evasion and of confrontation, it is also at least etymologically related to the feminine, and although it is by no means an 
exclusively female response, it lends itself to a critical examination of the contingent historical positioning of women (Gottlieb, 1999).

Hysteria has been connected to the female characters in literature for a long period of time, and the history is somehow coloured by these signs. As Helene Cixous says (1976), nearly the entire history of writing is confounded with the history of reason, one with the phallocentric tradition. Even though there were a lot of feminists analysing works by men, gynocriticism studied the writings of those women who, according to Elaine Showalter, produced a literature of their own (Murfin, 1999). Elaine Showalter defined three phases of women's writing: feminine (1840-1880), feminist (1880-1920), and female phase (1920 to the present) (Murfin, 1999). During the feminine phase women imitated masculine tradition, in the second phase they protested against its standards and values, and in the last phase they finally advocated their own and autonomous female perspective.

Apart from representing different historical periods and different writing styles, these three phases can also be used with the aim to analyse each particular female author since all of them follow these phases during the development of gender identity. The majority of feminists are trying to discover how women have come to be who they are through the history of their oppression by men and a male-designed world, but in most cases they decline to provide a key for understanding the socialization and symbolization processes which have shaped woman's specificity through the ages.

Lacan was convinced that „Totem and Taboo“ was completely wrong, therefore the Oedipus complex was Freud's own neurosis. According to Lacan, sex is correlated with identity rather than gender. The Oedipal crisis occurs, not because the child wants to posses its mother sexually, but when the child comprehends the sexual rules in a society (Ragland-Sullivan, 1982). The crisis can be resolved only when the rules are accepted and acceded to.

Contrary to Lacan, in Freud's writings woman is either a lesser, castrated man, or woman is mother, necessary ground for phallic reproduction (Gallop, 1980). He finds that children in the phallic phase hypothesize the anus as phallic receptacle, and attempt to think the 
familiar anus as the legendary maternal womb, therefore Luce Irigaray says that his theory appears to be arrested in the phallic phase (Gallop, 1980). Even Freud himself was conscious that he spoke about femininity in ways that did not always sound friendly to women (Moi, 2004).

One of the main differences between Freud and Lacan is that, while Freud focused on the psychic dynamics of transference as an intersubjective relationship, Lacan insisted that anyone can take up the symbolic position labelled masculine and feminine (Moi, 2004). He also insisted on the diference between the terms "penis" and "phallus", since the latter represents a lot more then just (erected) penis:

Paradoxical as this formulation might seem, I would say that this is in order to be the phallus, that is to say, the signifier of the desire of the Other, that the women will reject an essential part of her femininity, notably all its attributes through masquerade. It is for what she is not that she expects to be desired as well as loved. But she finds the signifier of her own desire in the body of the one to whom she addreses her demand for love. Certainly we should not forget that the organ actually invested with this signifying function on the value of a fetish (Lacan, 1966/2002, 84).

According to Toril Moi (2004), in Freudian and Lacanian theory castration is used in three different senses: to signify lack as a general human condition, to signify sexual difference or femininity, and, to signify the discovery of our own one-sexedness. But besides these similarities, Lacan found his own psychoanalysis based on two different systems of meaning: language and unconscious discourse, which, from the other side, gave him a special place in feminist criticism. As for Lacan, none will disagree that, throughout his teaching, he reserves a royal place for women, as well as the sobriquet „the Ladies' Man“ (Gallop, 1976). His understandings of the Oedipus complex and differences between penis and phallus ensure him that status, and also endow feminist theories with new ideas. 
Symbolic castration with the phallus as its signifier represents the gap between what she/he immediately is and the symbolic title which confers on her/him a certain status and authority. These symbolisation and socialization processes underlay the formation of female identity as such, and provide each women with certain rules which she might choose to play in a society. Then, among many neologisms of late Lacan, there is le sinthome, which represents "sinthom" as opposed to symptom. Sinthoms are a kind of "atoms of enjoyment," the minimal synthesis of language and enjoyment, units of signs permeated with enjoyment (Lacan. 1966/2002). According to Freud, nothing forces anyone to enjoy except the superego, which is the imperative of jouissance.

Jouissance refers to a pleasure or ecstasy beyond the phallus, therefore it gives another consistency to the women's writing and liberation movement. Following the analysis of Emmanuel Levinas, Walter Benjamin, and Giorgio Agamben, Zizek puts forth an unexpected hypothesis that links the object of pure life with the sinthom of shame. Since shame itself is a category of castration, and more specifically a Kantian auto-affection of respect for castration, phallic sinthome that belongs to a subject becomes overwhelmed by confrontation that there is a surplus-appendage in each person which remains non-castrated (Evans, 2008).

Jouissance represents a surplus of pleasure which remains after the recognition that castration and its disavowal are two sides of the same coin, recognized as inconsistency in Freud's discussion of the Medusa's Head:

It is remarkable fact that, however frightening the snakes may be in themselves, they nevertheless serve actually as a mitigation of horror, for they replace the penis, the absence of which is the cause of horror (Garber \& Vickers, 2003, 83-84).

Although itself a canonical representation of the terror and shame of castration, the Medusa ironically regulates its phallic anxieties by presenting to the viewer its head full of writhing snakes (Evans, 2008) This example shows how female identity generates from "phallic panic" 
attacks to the self-creation of jouissance and enjoyment. At the level of primary castration, both males and females experience loss, and gain an unconscious and a social personality, while at the secondary level this structural drama is substantivized, interpreted and explained (RaglandSullivan, 1982).

On the ground of the previously mentioned it is evident that each woman writer goes through three phases as described by Elaine Showalter. The main difference is that these three phases are not independent and merely historically connected, since they represent three phases of gender identity development: imitation of a masculine tradition, protest against its standards and values and finally, autonomous, female perspective. Lacan explained the first phase very deeply through the anecdote about competition between Zeuxis and Parrhasios, two painters from the ancient Greece, about who will paint a more lifelike and convincing picture. At the end, Zeuxis's painting was so convincing that the image was taken for the real thing, while in Parrahasios' painting one had the illusion that what could be seen is just a veil covering up the hidden truth.

For Lacan, that is how feminine masquerade works: she wears a mask to make people react like Zeuxis in front of Parrhasios' painting, which means that people want to see what is hidden under the mask. According to Lacan (1966/2002), a man can only pretend to be a woman, and only a woman can pretend to be a man who pretends to be a woman, as only a woman can pretend to be what she is. In order to explain that kind of female pretending (recognized as imitation by Showalter), Lacan refers to a woman who wears a concealed fake penis in order to evoke that she is phallus:

Such is woman concealed behind her veil: it is the absence of the penis that makes her the phallus, the object of desire. Evoke this absence in a more precise way by having her wear a cute fake one under a fancy dress, and you, or rather she, will have plenty to tell us about (Lacan, 1966/2002, 310). 
Phallus has the status of a mimicry which reveales something in so far as distinct from what might be called an itself that is behind (Lacan, 1973/1979). It does not fit the body and therefore remains hidden behind the image, hidden behind the feminine as long as she decides to object and, according to Showalter, produce something different from men's writing, produce l'ecriture feminine by the white ink of her gender.

\section{„Out of Flesh Out of Dictionaries": $m(O)$ ther and Childbirth Metaphor}

Identity is built up as a composite of images and effects, mental representations taken in from the outside world from the start of life, which are developed in relation to the desire for recognition and the later social requirements for submission to an arbitrary Law (RaglandSullivan, 1982). According to Lacan, the center of women's identity is $\mathrm{m}(\mathrm{O})$ ther, who is repressed as the real or primordial unconscious other, and thus is permanently linked to repression, denial, and loss of the truth of being (Ragland-Sullivan, 1982). These explanations are very important for understanding od Lacanian concept of female identity as well as female discourse.

By contrast, Melanie Klein held femininity to be innate and penisenvy but to breast-envy, to the oral and anal frustrations experienced by the child in relation to the mother, particularly in weaning and potty training (Sayers, 1987). According to Klein, girls already has inborn, unconscious knowledge of their father's penis. Nancy Chodorow, who has had an enormous influence on women's studies, revises the psychoanalytic concepts of self differentiation and says that it takes place in relation to the mother, who is a woman, and who becomes and remains for children of both genders the other, or the object (Showalter, 1981).

$\mathrm{M}(\mathrm{O})$ other has two meanings which are closely connected to the development of female identity: it represents the principle of loss, or it represents archaic corporal subject femininity relays on. Woman is the primordial other who speaks the discourse of the hidden truths of being, the face of God, therefore the answers to the mistery of identity lie in ascertaining repressed (m)Other's desire (Ragland-Sullivan, 1982). The biggest $\mathrm{m}(\mathrm{O})$ ther's desire, the prescribed one, lies in (pro)creation, the act 
of the body that reproduces the species. Contrary, creation is the act of the mind that brings something new into existence (Stanford-Friedman, 1987). Childbirth metaphor, the one that connects books and babies, also draws together mind and body, word and womb, division of labour and division of gender. The examples of such can be found in female writings and they often make an ambiguity between creation and procreation, pregnant body and pregnant mind:

... it is all blood and breaking

blood and breaking. the thing

drops out of its box squalling

into the light. they are both squalling,

animal and cage. her bars lie wet, open

and empty and she has made herself again

out of flesh out of dictionaries,

she is always emptying and it is all

the same wound the same blood the same breaking (Clifton, 1974, 50).

Woman can be both, mother and writer, creator and procreator. In the same way she gives birth to her child, she can give birth to her poems and novels. The childbirth metaphor evokes Lacan's formation of female gender identity, starting from hommelette, dual nature of human ego that is broken into two halves like the egg, to the $\mathrm{m}(\mathrm{O})$ ther, the symbol of creation and new discourse.

Apart of gender development, childbirth metaphor illustrates how gender complicates the reading and writing of texts. According to Stanford-Friedman (1987), male metaphor intensify difference and collision, while female metaphor enchance sameness and collusion. The female metaphor actually challenges both Showalter's phases and procreative unity of world and flesh, body and mind. The inscription of female body in the text becomes more then evident while evocing the strenght of female childbirth metaphor. Even though Cixous wrote about future inscription of femininity, women have subverted the regressive birth metaphor and transformed it into a sign representing their own delivery into speech through (pro)creativity (Stanford-Friedman, 1987). 
That is the last phase of the development of women's writing according to Showalter, or the last phase of the development of particular female author: possibility to control the labor of the mind pregnant with the word. The main sense of jouissance is not only the pure, simple pleasure, it is also the surplus of pleasure that arised from the prohibition. Most female authors create through the the different kinds of prohibitions: cultural prohibition of enjoyment, prohibition of particular type of behaviour, prohibition of talk or certain reaction... These prohibitions leave the consequences on their mind, body, soul, and help them to create specific anatomy of their texts.

Books will never be the same as babies, but the childbirth metaphor will always be serving as a specific surplus of $\mathrm{m}(\mathrm{O})$ ther discourse written in the white ink of female pen. While Virginia Woolf describes "feminine sentence", Judy Chicago identifies circular forms in the visual arts as female imagery (Stanford-Friedman, 1987). Chicago's "Birth Project" is based upon traditional creation myths but replace the concept of the male God with the female version due to its celebration of the birth-giving capacity of women along with their creative spirit (Davis, 2009).

Feminist art is not only about giving birth to the work, it is also about giving birth to the woman herself. The distinction of male and female discourse lies not in the metaphor by itself but rather in the way its final meaning is constituted in the process of reading, even though attempts to identify the sex of a writer or an artist without external clues often fail (Stanford-Friedman, 1987). Therefore, (Pro)creation and childbirth metaphor have also been recognized by male writers, like James Joyce in a letter to his wife Nora:

I went then into the backroom of the office and sitting at the table, thinking of the book I have written, the child which I have carried for years and years in the womb of imagination as you carried in your womb the children you love, and of how I had fed it day after day out of my brain and my memory. (Ellmann, 1975, 202-203) 
Hommelette and $\mathrm{m}(\mathrm{O})$ ther, man and woman, word and flesh, pen and womb, book and baby, are simultaneously drawn together in analogy but also separated in function. L'ecriture feminine as white ink of female discourse will promote different view of women's writing concidered through Showalter's three phases that are taken into account not only as historical facts, but rather as "writing of her own". By writing of her own woman is writing female history through ovarian prism and female discourse. That is jouissance of female writing: surplus of her powers and possibilities.

\section{Conclusion}

This article analyzed the psychoanalytic background of l'ecriture feminine and childbirth metaphor as illustration how gender complicates the reading and writing of texts. The paper signifies that the identity is built up through the processes of symbolization and socialization, as well as that Oedipus myth cannot be taken into consideration before previous analysis of the double castration and difference between phallus and penis. Lacan's psychoanalysis can be used in order to explain the formation of female identity through three historical phases as proposed by Elaine Showalter. Jouissance as the surpluse of enjoyment has its major role in explaining women's writing as a surpluse of prohibitions imposed by patriarchal society.

Women can be both creators and procreators, and each writing is metaphorical combination of both processes. Childbirth metaphor relies on organisation of culture and psyche, therefore it owes a lot to jouissance and sexual division of labor upon which Western patriarchy is founded. Nevertheless, it serves as an indicator of the real l'ecriture feminine based on the psychoanalytic formation of female identity. Male metaphor intensify difference and collision, while female metaphor enchance sameness and collusion. While the female metaphor challenges both three Showalter's phases and procreative unity of world and flesh, body and mind, the inscription of female body in the text is more then present when evocing the strenght of discourse.

The surplus of enjoyment serves also as the surplus of creative power that leads to the biological differentiation of both body and 
discourse. The pregnant mind hidden behind the image and the feminine produces something different from men's writing. That is the main point where l'ecriture feminine was born and enriched by the white ink of female gender. Linguistic reunion of culture, patriarchal literary tradition and female discourse emphasize jouissance of women's writing and its contribution to new literary ideas.

\section{References}

Barry, P. (2002). Beginning theory: An introduction to literary and cultural theory. New York: Manchester University Press.

Bovenschen, S., \& Weckmueller, B. (1977). Is there a feminine aesthetic? New German Critique, 10, 111-137.

Cixous, H. (1976). The laugh of the Medusa. Signs, 1 (4), 875-893.

Clifton, L. (1974). An ordinary woman. New York: Random House.

Davis, K. M. Interview with Judith Chicago. ArtLtdMag. Retrieved June 30 , 2011,

from

www.artltdmag.com/index.php?subaction=showfull

Ellmann, R. (1975). Selected letters of James Joyce. New York: Viking.

Evans, C. M. (2008). Hommelette's wild ride: lamella as a category of shame. International Journal of Zizek Studies, 2 (2), 1-19.

Gallop, J. (1980). Impertinent question: Irigaray, Sade, Lacan. SubStance 9 (1), 57-67.

Gallop, J. (1976). Review: The ladies' man. Diacritics 6 (4), 28-34.

Garber, M. B., \& Vickers, N. J. (2003). The medusa reader. New York: Routledge.

Gottlieb, S. (1999). The Nymph complaining for the death of her Faun: Marvell's Ovidian study in hysteria. Huntington Library Quarterly 62 (3/4), 273-294.

Kegan G., J. (1987). Self psychology as feminist theory. Signs 12 (4), 761-768.

Lacan, J. (2002). Écrits. A selection (B. Fink, Trans.). New York: W.W.Norton.

Lacan, J. (1983). Spisi (R. Kordic, Trans.). Beograd: Prosveta.

Lacan, J. (1979). The four fundamental concepts of psycho-analysis (A. Sheridan, Trans.). Harmondsworth: Penguin Books. 
Lorenzer, A. (1989). Intimnost i socijalna patnja (B. Buden, Trans.). Zagreb: Naprijed.

Moi, T. (2004). From femininity to finitude: Freud, Lacan, and Feminism, again. Signs 29 (3), 841-878.

Murfin, R. C. (1999). Feminist criticism and Jane Eyre. A Critical History, 460-465.

Ragland, S. E. (1982). Jacques Lacan: feminism and the problem of gender identity. SubStance 11 (3), 6-20.

Sayers, J. (1987). Melanie Klein, psychoanalysis, and feminism. Feminist Review 25, 23-37.

Showalter, E. (1981). Feminist criticism in the wilderness. Critical Inquiry 8 (2), 179-205.

Stanford, F. S. (1987). Creativity and the childbirth metaphor: gender difference in literary discourse. Feminist Studies 13 (1), 49-82.

Thomas, L. \& Webb, E. (1999). Writing from experience: the place of the personal in the French feminist writing. Feminist Review 61, 2748. 